\title{
PENELITIAN
}

\section{HUBUNGAN TINGKAT PENGETAHUAN TENTANG MENSTRUASI DENGAN DERAJAT DISMENORE PADA SISWI SEKOLAH MENENGAH ATAS DI PADANG TAHUN 2005}

\author{
Nelwati *
}

\begin{abstract}
Abstrak
Dismenore merupakan gangguan ginekologi yang paling sering ditemukan pada remaja wanita. Dismenore dapat dipengaruhi oleh beberapa faktor yaitu hormonal, psikis, neurologis, dan alergi. Pada keadaan yang berat, dismenore dapat menyebabkan gangguan terhadap aktivitas harian dan sekolah.

Telah dilakukan penelitian korelatif pada bulan Maret 2005 dengan 245 responden siswi Sekolah Menengah Atas di Padang. Pengambilan sampel dilakukan dengan proportional random sampling. Penelitian ini bertujuan untuk mengetahui hubungan tingkat pengetahuan remaja tentang menstruasi dengan derajat dismenore.

Hasil penelitian ini mendapatkan bahwa 30\% responden yang mempunyai pengetahuan kurang mengalami dismenore berat. Setelah dilakukan uji statistik dengan menggunakan chi square didapatkan hubungan yang bermakna antara tingkat pengetahuan siswi tentang menstruasi dengan derajat dismenore dengan nilai $\mathrm{p}=0,00$

Kesimpulan dari penelitian ini bahwa ada hubungan antara pengetahuan remaja tentang menstruasi dengan derajat dismenore, oleh karena itu pemberian informasi tentang menstruasi sangat penting bagi remaja yang dapat dilakukan oleh orang orang tua, guru, konselor maupun tenaga kesehatan. Pengetahuan tentang menstruasi akan memberikan kesiapan psikis pada remaja dalam menghadapi menstruasi khususnya yang disertai dismenore.
\end{abstract}

Kata kunci: gangguan ginekologi, menstruasi, remaja wanita

Abstract

Dysmenorrhea is the gynaecologic disorder that mostly experienced by female adolescents. Dysmenorrhea can be influenced by some factors like hormones, psycologic, neurologic and alergic. In severe condition, dysmenorrhea could cause daily and school activities disturbance. A correlation research had been conducted on March 2005 toward 245 female adolescent at Senior High School in Padang. Sampling was based on propotional random sampling. This research was aimed to identify correlation between knowledge about menstruation and grading of dysmenorrhea. This research showed that 30\% of respondent who have not adequate knowledge experience severe pain. After statistic testing with chi square, there are correlation between knowledge about menstruation and grading of dysmenorrhea with $p$ value $=0,00$. Conclusion of this researh is there was correlation between knowledge about menstruation with grading of dysmenorrhea. Providing information related to menstruation is very important for female adolescents by parents, teachers, conselors, as well as health care providers. Knowledge about menstruation will give readiness psychologically for female adolescents when they experienced menstruation disorders included dysmenorrhea.

Key words: : female adoslecent, gynaecologic disorders, menstruation

\section{LATAR BELAKANG}

Saat seseorang memasuki masa remaja terjadi berbagai perubahan baik fisik maupun mental. Pada remaja putri khususnya ditandai dengan dimulainya siklus menstruasi. Pada masa ini mereka seharusnya mendapat informasi yang akurat tentang menstruasi. Informasi tersebut misalnya proses terjadinya menstruasi, gangguan menstruasiyang mungkin terjadi, mitos atau kebiasaan yang ada di masyarakat yang berkaitan dengan menstruasi dan sebagainya. Informasi ini dapat diberikan oleh tenaga kesehatan, guru ataupun konselor (Malvia, 1994).

Beberapa gangguan menstruasi diantaranya adalah sindroma premenstruasi, amenore, dismenore, hipermenore dan hipomenore (Hanifa, 1994). Namun yang paling sering ditemukan diantara gangguan tersebut adalah dismenore. Hampir setiap hari para ahli ginekologi dikunjungi oleh wanita muda terutama yang belum menikah untuk konsultasi ataupun pengobatan karena dismenore yang dideritanya (Wynn, 1979). 
Jurnal Keperawatan Indonesia, Volume 10, No.1, Maret 2006; 1-4

Dismenore adalah nyeri yang timbul akibat kontraksi disritmik miometrium yang menampilkan satu atau lebih gejala, mulai dari nyeri ringan sampai berat pada perut bagian bawah, bokong dan pada sisi medial paha. Pada keadaan yang berat dapat disertai dengan berbagai gejala mulai dari mual, muntah, diare, pusing, nyeri kepala sampai pingsan (Baziad, dkk, 1990).

Terdapat $50 \%$ wanita mengalami nyeri panggul sebelum atau selama periode menstruasi dan sekitar $10 \%$ diantaranya mengalami kram yang cukup parah yang membuat mereka tak berdaya selama satu sampai tiga hari setiap bulan. Di Amerika Serikat, dismenore menyebabkan hilangnya 140 juta jam kerja setiap tahun. Meskipun dismenore tidak mengancam jiwa, tetapi merupakan penyebab utama wanita dibawah usia 30 tahun tidak bekerja. Hampir dua per tiga remaja post menarche di Amerika Serikat mengalami kram menstruasi yang nyeri, lebih dari $10 \%$ golongan ini begitu menderita sehingga harus absen dari sekolah, dan dengan demikian menempatkan dismenore sebagai penyebab utama absen dari sekolah jangka pendek pada remaja wanita (Schwarz, 1989).

Angka kejadian dismenore secara menyeluruh di Indonesia sampai saat ini belum dapat dikemukakan karena belum ada data yang lengkap. Pernah dilaporkan di Surabaya angka kejadian dismenore yaitu 1,07-1,31 $\%$ dari jumlah kunjungan penderita di poliklinik ginekologi. Namun angka kejadian ini lebih rendah dari keadaan yang sebenarnya karena tidak semua penderita dismenorre meminta pertolongan ke poliklinik ginekologi (Baziad, dkk, 1990). Salah satu faktor penyebab dismenore adalah faktor psikis. Faktor psikis ini dapat ditimbulkan oleh stres karena kurangnya pengetahuan remaja tentang menstruasi. Kurangnya pengetahuan remaja ini adalah akibat kurangnya informasi kesehatan yang benar dan kurangnya akses remaja terhadap pelayanan kesehatan reproduksi (Azwar, 2000), padahal mitos ataupun informasi yang salah tentang menstruasi akan mempengaruhi emosi dan gagap dalam menghadapi menstruasi (Hanifa, 1994).

Uraian mengenai dismenore tersebut jika dicermati dapat menimbulkan masalah penelitian mengenai hubungan tingkat pengetahuan siswi tentang menstruasi dengan derajat dismenore. Oleh karena itu, telah dilakukan penelitian di sebuah Sekolah Menengah Atas di Padang, Sumatera Barat.

\section{METODE}

Penelitian ini merupakan penelitian deskriptif korelasi dengan pendekatan cross sectional. Variabel independen penelitian ini adalah tingkat pengetahuan remaja tentang menstruasi yaitu definisi, proses terjadinya menstruasi, mitos tentang menstruasi, definisi, penyebab dan cara penanggulangan dismenore dengan skala ordinal. Hasil ukurnya dengan kategori baik, bila skor $>56 \%$ dan kategori kurang, bila skor $<56 \%$. Variabel dependen adalah derajat dismenore yaitu respon remaja terhadap dismenore dengan skala ordinal. Hasil ukurnya dengan derajat 1 : nyeri ringan, jarang memerlukan analgesik dan jarang menganggu aktivitas sehari-hari, derajat 2 : nyeri sedang, memerlukan analgesik, aktivitas sehari-hari terganggu tetapi jarang absen dari sekolah, derajat 3 : nyeri berat, nyeri tidak banyak berkurang dengan analgesik, tidak dapat melakukan aktivitas sehari-hari, timbul keluhan vegetatif seperti nyeri kepala, kelelahan, mual, muntah, dan diare.

Penelitian ini dilaksanakan di sebuah Sekolah Menengah Atas di Padang, Sumatera Barat dengan pengambilan data di lakukan padabulan Maret 2005. Jumlah populasi 710 orang siswi dengan rumus Lovin didapat sampel 256 orang siswi. Pengumpulan data dengan menggunakan kuesioner dan setelah data didapatkan maka datadiolah dengan anal isauni variat dan bivariat dengan uji statistik Chi-Square dengan derajat kemaknaan $95 \%$.

\section{HASIL}

Pengambilan data penelitian ini dilaksanakan selama lima hari di bulan Maret 2005 dengan 256 responden. Namun setelah data dikumpulkan 11 orang responden tidak memenuhi kriteria sampel karena tidak mengalami dismenore sehingga responden menjadi 245 orang.

Tabel 1

Distribusi Frekuensi Responden Berdasarkan Pengetahuan tentang Menstruasi

Pada Siswi Sekolah Menengah Atas di Padang Tahun 2005

\begin{tabular}{crc}
\hline Tingkat Pengetahuan & f & \% \\
\hline Baik & 205 & 83.7 \\
Kurang & 40 & 16.3 \\
\hline Jumlah & $\mathbf{2 4 5}$ & $\mathbf{1 0 0 . 0}$ \\
\hline
\end{tabular}


Tabel 2

Distribusi Frekuensi Responden Berdasarkan Derajat Dismenore

Pada Siswi Sekolah Menengah Atas di Padang Tahun 2005

\begin{tabular}{crr}
\hline Derajat Dismenore & \multicolumn{1}{c}{ f } & \multicolumn{1}{c}{$\%$} \\
\hline Ringan & 182 & 74.3 \\
Sedang & 47 & 19.2 \\
Berat & 16 & 6.5 \\
\hline Jumah & $\mathbf{2 4 5}$ & $\mathbf{1 0 0 . 0}$ \\
\hline
\end{tabular}

Tabel 3

Hubungan Pengetahuan Tentang Menstruasi dengan Derajat Dismenore Pada Siswi Sekolah Menengah Atas di Padang

Tahun 2005

\begin{tabular}{|c|c|c|c|c|c|c|c|c|}
\hline \multirow{3}{*}{$\begin{array}{c}\text { Tingkat } \\
\text { Pengetahuan }\end{array}$} & \multicolumn{6}{|c|}{ Derajat Dismenore } & \multicolumn{2}{|c|}{ Jumlah } \\
\hline & \multicolumn{2}{|c|}{ Ringan } & \multicolumn{2}{|c|}{ Sedang } & \multicolumn{2}{|r|}{ Berat } & \multirow[b]{2}{*}{$\mathbf{f}$} & \multirow[b]{2}{*}{$\%$} \\
\hline & $\mathbf{f}$ & $\%$ & $\mathbf{f}$ & $\%$ & $\mathbf{f}$ & $\%$ & & \\
\hline Baik & 179 & 87.3 & 22 & 10.7 & 4 & 2.0 & 205 & 100 \\
\hline Kurang & 3 & 7.5 & 25 & 62.5 & 12 & 30.0 & 40 & 100 \\
\hline Total & 182 & 74.3 & 47 & 19.2 & 16 & 32.0 & 245 & 100 \\
\hline
\end{tabular}

Dari tabel 1, terlihat pengetahuan siswi tentang menstruasi sebanyak $83.7 \%$ orang responden mempunyai pengetahuan yang baik dan sebanyak $16.3 \%$ responden mempunyai pengetahuan yang kurang.

Sedangkan dari tabel 2 , terlihat sebanyak $74.3 \%$ responden menderita dismenore ringan, $19.2 \%$ dengan dismenore sedang, dan $6.5 \%$ responden dengan dismenore berat

\section{PEMBAHASAN}

Berdasarkan hasil penelitian dapat dilihat pada tabel 1 bahwa terdapat $83.7 \%$ responden sudah mempunyai pengetahuan yang baik. Pengetahuan responden yang sudah baik dapat disebabkan karena responden sudah mendapatkan informasi, salah satunya melalui pelajaran biologi yang telah mereka dapatkan sejak di Sekolah Dasar ataupun di Sekolah Menengah Pertama. Bila dikaitkan dengan usia menarche responden yaitu usia 11-15 tahun tentunya informasi tersebut sangat relevan dengan kondisi menarche maupun post menarce yang mereka alami. Tingkat pengetahuan yang baik juga bisa disebabkan oleh letak Sekolah Menengah Atas (SMA) yang menjadi lokasi penelitian terletak di pusat kota, sehingga memungkinkan siswi SMA tersebut terpapar dengan banyak media informasi baik media cetak maupun elektronik.

Pengetahuan tentang menstruasi sangat penting diberikan pada remaja karena akan mempengaruhi psikis remaja dalam menghadapi menstruasi. Hal ini sesuai dengan pendapat Hanifa (1994), bahwa informasi yang salah tentang menstruasi akan mempengaruhi emosi dan gagap dalam menghadapi menstruasi seperti perasaan takut, bingung dengan kondisi yang dialaminya.

Berdasarkan tabel 2 dapat diketahui $74.3 \%$ responden mengalami dismenore ringan, $19.2 \%$ responden mengalami dismenore sedang dan $6.5 \%$ responden mengalami dismenore berat. Dismenore tidak hanya menyebabkan ketidaknyamanan bagi remaja tetapi juga akan mempengaruhi baik fisik, psikis, sosial, dan ekonomi. Pada dismenore berat akan timbul gejala lain seperti mual, muntah, diare dan pingsan. Keadaan ini tentunya sangat mempengaruhi kondisi fisik remaja, sehingga menghalangi remaja untuk beraktivitas. Dismenore berat akan menyebabkan remaja absen dari sekolah. Menurut penelitian oleh Schwarz (1989), bahwa dismenore adalah penyebab utama absen dari sekolah jangka pendek pada remaja wanita. Pada kegiatan seperti olah raga dismenore menyebabkan mereka tidak dapat mengikuti kegiatan tersebut. Selain itu dismenore bisa menurunkan konsentrasi belajar dan bila mereka sedang menghadapi ujian akan memberikan dampak rendahnya nilai yang mereka dapatkan. Keadaaan ini akan mempengaruhi prestasi akademik di sekolah. Keadaan ini juga didukung oleh hasil penelitian Tangchai (2004), melaporkan $6.5 \%$ responden dengan dismenore berat mendapatkan nilai yang rendah dan $80.6 \%$ harus absen dari sekolah.

Dismenore dan dampak yang ditimbulkannya sangat penting disosialisasikan bagi remaja, orang tua dan guru. Penanggulangan dismenore ini dapat dilakukan diantaranya dengan memberikan penjelasan yang benar mengenai menstruasi dan dismenore yang dapat dilakukan baik oleh guru maupun orang tua, disamping itu juga penting untuk memberikan pendidikan kesehatan tentang cara mengurangi nyeri yang efektif pada remaja. 
Jurnal Keperawatan Indonesia, Volume 10, No.1, Maret 2006; 1-4

Pada tabel 3 dapat dilihat bahwa adanya hubungan yang bermakna antara tingkat pengetahuan remaja tentang menstruasi dengan derajat dismenore $(\mathrm{p}=0.00)$. Pada penelitian ini $87.3 \%$ responden yang mempunyai pengetahuan baik mengalami dismenore derajat ringan dan $30 \%$ responden yang mempunyai pengetahuan kurang mengalami dismenore berat. Pengetahuan dapat memberikan kesiapan mental bagi seseorang dalam menghadapi suatu kondisi. Pengetahuan tentang menstruasi, dismenore dan cara penanggulangannya menyebabkan remaja lebih siap karena mengetahui apa yang terjadi pada diri mereka selama mengalami menstruasi dan dismenore. Dengan pengetahuan dan dismenore yang dialami juga akan menimbulkan kemampuan adaptasi terhadap dismenore. Selain itu remaja juga dapat melakukan upaya meredakan dismenore dengan pengetahuan yang sudah mereka ketahui. Hal ini sesuai dengan tingkat domain kognitif yaitu aplikasi dimana seseorang mengaplikasikan sesuatu yang ia ketahui dalam menghadapi suatu kondisi (Notoatmodjo, 2003). Kesiapan mental yang ditunjang oleh pengetahuan yang baik akan menciptakan kondisi psikis yang baik pula yang akan mempengaruhi respon terhadap nyeri. Individu dengan kondisi psikis yang baik akan lebih toleran terhadap nyeri yang timbul (Brunner \& Suddarth, 2000).

Adanya responden yang mempunyai pengetahuan yang baik tetapi mengalami dismenore berat $2 \%$ dan responden yang mempunyai pengetahuan yang kurang tetapi mengalami dismenore sedang $7.5 \%$ dapat disebabkan oleh berbagai faktor, antara lain faktor hormonal, neurologis, alergi, dan sebagainya.

Pengetahuan tentang menstruasi sangat penting diberikan bagi remaja sesuai dengan pendapat Hanifa (1994), bahwa pengetahuan akan mempengaruhi psikis remaja dalam menghadapi menstruasi. Pengetahuan yang baik akan memberikan kemampuan bagi remaja untuk beradaptasi terhadap dismenore sebaliknya pengetahuan yang kurang akan mempengaruhi emosi remaja dalam menghadapi menstruasi sehingga dapat merangsang respon simpatis yang akan meningkatkan respon terhadap dismenore.

\section{KESIMPULAN}

Pengetahuan tentang menstruasi, dismenore dan cara penanggulangannya akan memberikan kesiapan mental remaja untuk beradaptasi dengan kondisi fisiologis yang sedang mereka alami. Persiapan mental yang ditunjang dengan pengetahuan yang baik akan menciptakan kondisi psikis yang mempengaruhi respon remaja terhadap dismenore tersebut.

Hasil penelitian ini menyarankan kepada para guru untuk memberi perhatian khusus bagi siswi yang mengalami dismenore sedang dan berat dengan melakukan kontak secara rutin antara orangtua siswi yang menderita dismenore dan guru dalam mengatasi dampak dismenore tersebut. Selain itu, perlu kerjasama antara Unit Kesehatan Sekolah dengan institusi kesehatan ataupun lembaga yang peduli dengan kesehatan reproduksi remaja dalam memberikan pendidikan kesehatan bagi remaja.(INR)

* Nelwati S.Kp.: Staf Akademik Program Studi Imu Keperawatan Fakultas Kedokteran Universitas Andalas, Padang

\section{KEPUSTAKAAN}

Baziad,A, dkk. (1990). Dismenorea aspek patofisiologi dan penatalaksanaannya. Jakarta : FKUI.

Brunner, L.S., and Suddarth, D.S. (2000). Keperawatan medikal bedah, Jakarta: EGC. (Terjemahan)

Hanifa, W.S. (1994). Ilmu kandungan. Edisi 2. Jakarta : Yayasan Bina Pustaka Sarwono Prihardjo.

Malvia, V. (1994). Medical book obstetic and gynaecology diagnosis and treatment. $\left(8^{\text {th }} \mathrm{ed}\right)$. New York : Appleton \& Lange.

Notoatmodjo, S. (1993). Metodologi penelitian kesehatan. Jakarta : Rineka Cipta.

Notoatmodjo, S. (2003) Pendidikan kesehatan dan ilmu perilaku kesehatan. Jogjakarta : Andi Offset.

Schwarz, B.E. (1989). Dysmenorrhea in gynaecology. Washington : Addisson.

Tangchai, K. (2004). Dysmenorrh ea in Thai adolecents : Prevalence, impact and knowledge of treatment. Volume 12, hal 23-25. Thailand : J Med Assoc.

Wynn,R. (1979). Obstetric and gynaecology the clinical care. $\left(2^{\text {nd }} \mathrm{ed}\right)$. Philadelpia : Lea and Febiger. 